\title{
Noir Than Ever: \\ Crime Drama as the Popular Genre in Turkish Streaming Services
}

\author{
Nisa YIldirim \\ Istanbul Gelisim University Faculty of Economics, Administrative and Social Sciences \\ https://orcid.org/0000-0002-7941-4470 \\ nyildirim@gelisim.edu.tr
}

\begin{abstract}
The article focuses on the original series of Turkish streaming services Blu TV and Puhu TV released between 2017 and 2020 in terms of genre, and aims to discover their differences from the traditional television series having highly conservative narratives. After identifying that the crime drama genre is primarily preferred by these services, the ideological approach of genre analysis is adopted to study four series which are Masum (Innocent), Bozkir (Steppe), Șahsiyet (Persona), and Dip (Base). It is found that all four of the series share a common pessimism in a social context which is created by representing the evil as omnipotent and all members of the society as more or less victims. In addition, depicting the status quo as unchangeable strengthens the emphasis on -no escape- in general. It is possible to criticize these narratives for normalizing dysfunctional legal system, and neutralizing the prospect for improvement. In conclusion, the article claims that what these new series offer are far from being progressive, despite the freedom of their medium.
\end{abstract}

Keywords: Streaming services, genre, series, Turkish series, crime drama

Received: 01.03.2021 • Accepted: 15.11.2021

http://ilefdergisi.ankara.edu.tr

ilef dergisi • @ 2021 • Özel Sayı • güz/autumn: 127-148

Araștırma Makalesi DOI: 10.24955/ilef.1038640 


\title{
Her Zamankinden
}

\section{Daha Karanlık:}

\section{Yerli Dijital Platform Dizilerinde Popüler} Tür olarak Suç Dramaları

\author{
Nisa Yıldırım \\ Istanbul Gelișim Üniversitesi İktisadi, İdari ve Sosyal Bilimler Fakültesi \\ https://orcid.org/0000-0002-7941-4470 \\ nyildirim@gelisim.edu.tr
}

Öz

Makale, yerli dijital platformlar Blu TV ve Puhu TV'nin 2017-2020 yılları arasında yayınladığı dizilerin türlerine odaklanarak, bu dizilerdeki anlatıların, fazlasıyla muhafazakâr olan geleneksel televizyon dizileri arasındaki farklııklarını keșfetmeyi amaçlamaktadır. Suç draması türünün bu platformlarca sıkı|kla tercih edildiği tespit edildikten sonra Masum, Bozkır, Șahsiyet ve Dip adlı diziler tür analizi yönteminin ideolojik yaklașımı benimsenerek incelenmiștir. Seçilen dört dizinin toplumsal bağlamda benzer bir karamsarlığı paylaștığı görülmektedir. Buna gerekçe olarak ise kötüye sınırsız güç atfedilerek toplum üyelerinin her birinin az ya da çok kurban olarak temsil edilmesi gösterilebilir. Ayrıca statükonun değiștirilemez olarak tasvir edilmesi kaçıșsızlığa yapılan vurguyu güçlendirmektedir. Bu nedenle söz konusu anlatıların ișlevsiz hukuk sistemini normalleștirmeleri ve iyileșme beklentisini nötralize etmeleri nedeniyle eleștirilmesi mümkündür. Sonuç olarak makale, bu yeni dizilerin, mecralarının sunduğu özgürlüğe rağmen progresif anlatılar olmaktan uzak olduklarını iddia eder.

Anahtar Kelimeler: Dijital platformlar, tür, diziler, Türk dizileri, suç draması

Makale geliș tarihi: 01.03.2021 • Makale kabul tarihi: 15.11.2021

http://ilefdergisi.ankara.edu.tr

ilef dergisi - ( 2021 - Özel Sayı • güz/autumn: 127-148

Research Article DOI: 10.24955/ilef.1038640 


\section{Introduction ${ }^{1}$}

Viewing habits of the audience in Turkey have begun to change since the launch of Turkish streaming services BluTV and Puhu TV in 2016, besides the arrival of Netflix TR. These services, which offer foreign films and television series to their audience, have created a group of audience who is familiar with cinematic aesthetics and demands diversity in the narratives. As a result, the contents that are being provided by broadcast television channels have been criticized for their low quality when they are compared with the globally popular TV shows or cinema films having creative narratives. In addition, it is possible to claim that the original productions of streaming services began to make the line between cinema and television get blurred, and these services began to function as 'quality television'. According to Pearson (2007, 244-245) "narrative complexity" is the "hallmark of the quality television" which made the television and cinema inseparable. Different from the narratives, televisi-

1 Bu çalışma yazarın 2020 yılında Prof. Dr. Nilay Ulusoy danışmanlığında Bahçeşehir Üniversitesi Sosyal Bilimler Enstitüsü Sinema ve Medya Araştırmaları Programı'nda yürüttüğü "Post-Television Era in Turkey: An Analysis of Local TV Series Genres by Streaming Services" başlıklı doktora tezinden türetilmiştir 
on as a device also adapts itself to the new standards of the industry to attract the audience by offering maximum visual pleasure. As the sizes of television screens get wider and the quality of resolution and sound improves, the line between cinema and television begins to blur (Tüzün-Ateşalp 2016, 14).

In terms of quality television, it is possible to claim that, traditional television series in Turkey cannot satisfy a group of audience. Since the duration of television series have begun to reach, even exceed three hours, they blocked the prime-time, which means they had to be produced in accordance with particular broadcasting obligations offered by RTÜK. These series in general had to be 'family-friendly', not including nudity, alcohol, or cigarettes. As a result of these restrictions, particular genres like melodrama or comedy-dramas that allow building on conservative narratives invaded the screens in the evening. According to Tüzün-Ateşalp $(2016,33)$ television channels aim to reach the broadest number of audiences by addressing the average tastes, and provide the maintenance of audience by attracting them every week by television series.

Streaming services aiming to attract the audience who are not happy with the content provided by traditional television have been preferring the drama genres which rarely appear on television. In 2019, streaming services in Turkey were threatened by RTÜK about possible censorship for using nudity, alcohol, and cigarette that would limit their freedom on storytelling, which is their only bullet to compete with the television and cinema industry. Media professionals reacted negatively and criticized such an attempt that would harm the industry by hindering the efficient use of a new medium and possible investments. As the rumors continue about upcoming restrictions, a new regulation was declared in August 2019 and these services became obliged to buy a license to continue streaming which costs 100.000 Turkish Liras. ("Internet televizyonlarına RTÜK denetimi geldi" 2019). Besides buying licenses, streaming services began to use "viewer age range smart signs" for each content.

\section{Distribution of Drama Genres in Turkish Streaming Services Series}

According to the data shared by Şentürk $(2018,20)$ comedy, drama, and melodrama are the genres that dominate the Turkish television series, and the genres of television series that were broadcasted between 2011 and 2015 distributed as drama/melodrama for $60 \%$, comedy for $31 \%$. Even though melodrama is the dominant genre of traditional television series in Turkey, it is not 
possible to claim that crime drama is totally abandoned on television. Police procedural Arka Sokaklar (Back Streets, Kanal D) which is about a group of police commissioners who have to secure the city while trying to be good fathers, husbands, or lovers, continues to meet the audience since 2006. Another police procedural Behzat Ç. was released in 2010 and managed to have its unique audience group which can also be defined as "fans". On the other hand, crime/action drama Kurtlar Vadisi (Valley of the Wolves, Show TV, 2003) had been on the series which had the highest rating results in Turkish television history, and it inspired the following television series revolving around mafia leaders like recent examples Eşkıya Dünyaya Hükümdar Olmaz (Bandit Cannot Be Emperor to the World, ATV, 2015 -) and Çukur (The Pit, Show TV, 2017-2021). These crime dramas also have a melodramatic tone in their narratives which are build on "romance" besides law-and-order discourse. Due to the characteristics of melodrama which depicts a totally black and white universe (Arslan 2005, 39), these series also have similar universes where there is a clear division between good and bad, right and wrong. If the dominant masculine discourse in their narratives is also considered while evaluating these series, it can be claimed that they are unsurprisingly conservative in accordance with the discourse of traditional television.

Table 1. Genres of the Turkish streaming services series between 2017-2020

\begin{tabular}{|c|c|c|c|c|c|}
\hline & Crime & Comedy & Drama & Fantastic & Horror \\
\hline \multirow{3}{*}{ BluTV } & $\begin{array}{l}\text { Masum } \\
\text { (Innocent) }\end{array}$ & $\begin{array}{c}\text { Dudullu } \\
\text { Postası } \\
\text { (Dudullu Post) }\end{array}$ & $\begin{array}{c}7 \text { yüz } \\
\text { (7Faces) }\end{array}$ & & $\begin{array}{c}\text { Sahipli } \\
\text { (Possessed) }\end{array}$ \\
\hline & $\begin{array}{c}\text { Bozkır } \\
\text { (Steppe) }\end{array}$ & $\begin{array}{c}\text { Bartu Ben } \\
\text { (It's me,Bartu) }\end{array}$ & & \multirow{2}{*}{$\begin{array}{l}\text { Yașamayanlar } \\
\text { (The Ones Who } \\
\text { Do Not Live) }\end{array}$} & \\
\hline & $\begin{array}{l}\text { Sifir } 1 \text { (Lero 1) } \\
\text { Behzat Ç. }\end{array}$ & $\begin{array}{c}\text { Aynen Aynen } \\
\text { (Exactly) }\end{array}$ & & & \\
\hline $\begin{array}{l}\text { Puhu } \\
\text { TV }\end{array}$ & $\begin{array}{l}\text { Sahsiyet } \\
\text { (Persona) } \\
\text { Dip (Base) }\end{array}$ & $\begin{array}{l}\text { Jet Sosyete } \\
\text { (Jet Set) }\end{array}$ & Fi\& Çi & & \\
\hline
\end{tabular}


As it can be seen in Table 1, crime drama was the most popular genre among the distribution of genres in Turkish streaming service series in their first three years. BluTV also released three new crime dramas like Sokağın Çocuklarn (Kids of The Street), Alef (Alef) and Saygz (Respect) in its fourth year. Comedy appears as the second popular genre with four series in total. However, only two of them: Dudullu Postası (Dudullu Post) and Bartu Ben (It's me, Bartu) are original streaming service contents, while other two are "transferred" productions.

Cooke $(2008,29)$ points out that television industries all over the world which have been facing a decrease in audience shares lately, re-discovered the crime/detective drama genre. This genre manages the hook the audience easily while allowing its creators to follow similar formulas again and again by relying on the law-and-order discourse. This research aims to discover what the narratives of Turkish streamed crime dramas offer as 'new', and if they manage to differ from traditional television series.

\section{Crime Drama as a Lifesaver}

The popularity of crime drama genre can be interpreted as an easy strategy of streaming services aiming to attract the audience who are not happy with the content provided by traditional television. Being freed from the constraints of RTÜK had also allowed them to use sexuality, alcohol, or cigarettes, including violence or blood which are part of the crime drama narratives.

In the following part of the article, four of the crime drama series: Masum (Innocent, BluTV), Bozkır (Steppe, BluTV), Şahsiyet (Persona, Puhu TV) and Dip (Base, Puhu TV) are studied by adopting the genre analysis method. BluTV had also launched two more crime drama series like Behzat Ç. which was previously produced as a television series, and Sifir 1 (Zero 1) which was a YouTube series before it was transferred by BluTV in its third season. While selecting the series as cases of the article, these two series were excluded due to not being created as a original streaming service project since their development processes.

The four series that were chosen as cases have a common feature which is using the battle between good and evil as a theme in general. The battle between good and evil is the broadest theme that is used by almost all narratives in literature, cinema, or television to build their conflict on. However, it is more apparent in some genres than others. Crime dramas and fantasy dramas 
-with their criminals and villains- are the two genres that underline this unending battle more when they are compared with others.

In order to identify the genres of series, the similarities which will be considered are "comparable plots or formulaic narrative structures; typical situations; stereotypical characters; analogous themes and patterns" (Andrews 2014, 9). By adopting the ideological approach of genre analysis, the main themes of these series will be identified, and their narratives will be discussed in terms of gender conflicts and the distrust in the police and juridical system.

\section{Dilemma of a Father-of-two: Masum}

Blu TV introduced its first original content Masum on 27 January 2017, one year after its launch. The series spanned eight episodes by weekly releases each has durations from 44 to 59 minutes. In terms of genre, Masum can be categorized under the crime/detective drama genre, while its subgenre is a psychological thriller which makes the series differ from a classic "whodunit". In Masum, the criminals, victims, and their folks all suffer from emotional dilemmas creating a moral ambiguity, and all of them are stuck in between situations creating a great inescapability for them. Moreover, Masum uses flashback scenes frequently which means its narration does not have a chronological storyline. All these features of the series make it have noir elements both in its style and theme. As Neale (2000a, 164) points out, flashback, voiceover, and highly contrasted lighting are stylistic features of noir, while the concerns in noir narratives are build on: "the focus on mentally, emotionally, and physically vulnerable characters, the interest in psychology, the culture of distrust marking relations between male and female characters, and the downbeat emphasis on violence, anxiety, death, crime, and compromised morality."

Masum underlines the impossibility of a rescue from its nightmarish world by not punishing the evil in the end, despite punishing all victims. The protagonist of the story is a retired police commissioner who helps his two sons on covering the crime they committed and getting rid of the evidences. As Cobb (1992, 207-209) points out, noir characters used to be constructed as "unsympathetic".

The audience feels little sympathy for the characters and their situations because they are not likable personalities and they do forbidden things. If the movie audience cannot feel sympathy for the characters, then they care little about what happens to them and cannot connect to the story on an emotional level. So, the 
keys to linking the audience to noir characters are understanding and intrigue. A viewer may not especially like a noir protagonist, but if there is enough understanding of why a character is a way he is, of how he got to this wretched place in his life, then the audience will be interested in what happens in the end.

On the other hand, in film noir criminals used to be "ordinary citizens" instead of "professional" criminals. This person is "drawn into crime by accident or some strange, unforeseen combination of factors" (Fluck 2009, 289). Masum's criminal does not plan to commit a crime, however, everything happens all of a sudden when he meets an unexpected situation. Furthermore, the unrest created in film noir mostly depends on plot twists rather than violence (Borde and Chaumeton 1955, 23). In the surprising final of Masum, the real identity of a secondary character is revealed and the viewer's perception of the criminal changes at the last minute.

As a crime drama, the storyline of Masum is built on the reopening of a car accident case due to a "missing body", while its theme focuses on male violence against women. The misery of a married woman who is forced to be the mistress of a chief of police, begins to impact others around her indirectly, and her husband who has been innocent in the beginning becomes a man full of hatred towards all women and he turns into the murderer of two.

In terms of gender, Masum adopts a patriarchal discourse, by representing the mother as a woman who does not like the wives of her two sons due to their lack of housework skills. Besides the mean mother-in-law figure, the two young women have a distant relationship and there is no solidarity between them. On the other hand, these two women are victimized in the maledominated world, they are manipulated, threatened, deceived, hurt, and in the end, one of them is killed, the other one captured by a torturer.

Film noir narratives are structured by a patriarchal logic in which women are always framed as less than men (Tasker 2013,355). Men of the series used to perform masculinity both physically and verbally. When Cevdet -the protagonist- quarrels with her wife, he humiliates women by complaining about women's unending speaking. He tells her "Even we didn't use such a method like your way of speaking in the tortures." Especially Cevdet and policeman Yusuf use swearwords very often. Yusuf uses slang words in his daily conversations and he is warned by his ex-wife not to use them when he is talking to her and their daughter. At the beginning of the first episode, a friend of Yusuf who is also a policeman tells him that he is going be the father of a son 
soon and Yusuf congratulates him by telling "Well done!" to emphasize the gender of the child. Cevdet's son Taner who is deceived by his wife Rüya, says "I've become the wife of my wife" to explain how insufficient he feels like a man and a husband. Taner's description as being the wife of his wife reflects Taner's way of thinking about women and necessitates of being a man and husband which requires absolute authority.

Ideologically, Masum questions police legitimacy. Cevdet is a retired policeman trying to save his two sons from being arrested due to the murders they committed, and he uses all the experience he had as a policeman to get rid of the evidences. Cevdet defends himself by uttering an excuse about "being a father" which creates a moral ambivalence. It can be argued that more questioning of police legitimacy is made over Selahattin: the chief of police who is the real "evil." As Woodhouse $(2001,148)$ explains:

Fictional representations of the police offer a means for society to understand the conflicts and contradictions that involve the upholding of the law and the relationship between the police detective, the criminal, and society as a whole. This inevitably raises ideological issues: the conflict between villain and hero can be perceived as a conflict between contrasting ideological positions.

Despite his failure in the case, detective Yusuf fulfills the position of a hero in Masum, due to both working for maintaining the law-and-order while being manipulated and being employed by the villain Selahattin who is also responsible for the maintenance of law and order. When Yusuf works on the investigation, his chief Selahattin warns him to be "more sensitive" if he is on a case related to someone from the police forces. Yusuf realizes that Cevdet had used his influence on the police and warned Selahattin to close the case. However, Cevdet and Selahattin meet soon after in the interrogation room where they argue and Cevdet insults Selahattin by revealing his dangerous desires which are beating and assaulting women. His words reveal that Cevdet knows Selahattin's sadistic personality for a long time. However, Selahattin had no punishment since he had started his abuses to women because his power made him untouchable and even, he became the chief of police. The man whose crimes are ignored by Cevdet becomes the main reason for his family's end. However, Selahattin can save himself in the end once again, moreover, he gets rid of Taner who was trying to save Rüya. Masum breaks the fourth wall in the final by letting Rüya look at the viewers' eyes to make them feel guilty about her despair and even share the responsibility of the ones who help "evil" by ignoring his crimes. 
Figure 1. The Evil in the final scene of Masum, Source: Blutv.com Masum
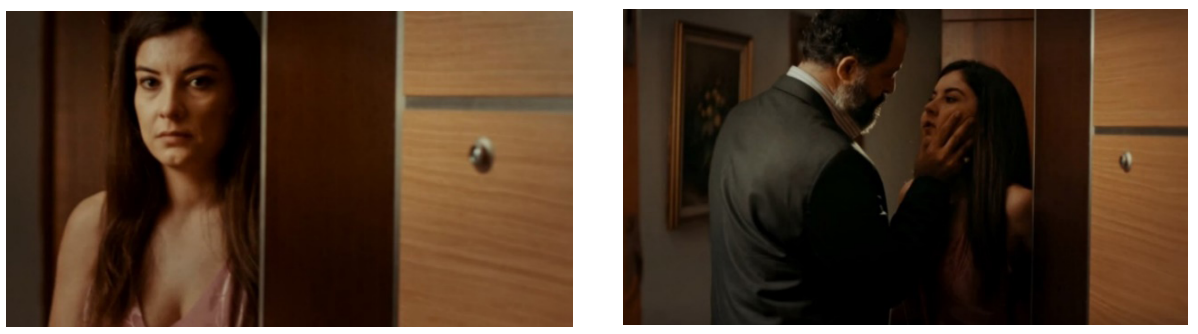

\section{Silence Hides the Crime: Bozkır (Steppe)}

Blu TV released the first episode of Bozkır on 30 November 2018 and it spanned ten episodes, with a duration of 55 to 60 minutes each. Bozkır is a whodunit crime drama that is close to classic noir with its definite stereotypes: the detective, femme fatale, and the evil. When it is compared with the previous noirish crime drama of Blu TV: Masum, the difference between good and evil is clearer in Bozkır which makes its moral ambiguity less. The protagonist of the series is a police commissioner living in a small town whose despair does not end during the story, and he has to live on without expecting a positive change in his life. He suffers both isolation and alienation as a typical noir protagonist (Cobb 1992, 211- 212). Bozkir is based in a small town where the crime hides beyond a false peace appearing in daylight. The protagonist used to wander around in quiet places of the town. He used to eat sandwiches in his car or while he is sitting on a bench or under a tree. As Dyer (1977) notes:

For films noir set in the country, the country is as desolate in its way as the city landscapes. Settings tend to be in the public world rather than domestic. For the hero, a basic domestic ritual like eating is transferred from family to public eating place. In this way, the hero is denied an environment of safety, coziness, or rootedness.

As Rogers $(2008,81)$ points out, it becomes apparent that even intertextual references within the television police genre seem to be governed to some extent by national attributes and cultural context. Bozkır's theme is based on child abuse and murders that occurred in a conservative small town. The child abuse and murders committed in Turkey always create social indignations among society and the number of cases is increasing in the last decade. Lately, in 2018, the society had responded to the two different cases about small girls in Ankara and Ağr1. In July of 2018, a group of people got together 
in Taksim to protest the rising number of cases in Turkey. The cases had underlined the inefficiency of law on the crime of child abuse and murders, and even the castration penalty had been mentioned which had been aimed to be disincentive (Kasapoğlu and Kaytazoğlu, 2018).

In Bozkır, some men commit murders, some little boys are assaulted and killed, and some men try to stop the crime and provide justice. As a result, it talks about the world of men where women have only a limited impact on the order of that world. In terms of gender, it can also be argued that Bozkir is a reformist work due to having LGBT characters which are rarely seen in Turkish television series. However, the way of representing these characters does not make the series supportive for LGBT. Abbas, the evil, is a bisexual man who gets pleasure from killing small boys, and his ex-partner is a homosexual having a sadistic personality like Abbas. The third LGBT character of Bozkır is a male belly dancer who is also not innocent. He used to complain about the difficulty of living in a town as a homosexual man and he says "being faggot is not easy" to make the one he talks to feel pity for him. However, he has a dependent personality and helps the man whom he loves for years to hide the kidnapped boy. On the other hand, heterosexual characters are not emotionally satisfied too. They cannot manage to keep up proper relationships or their dreams do not come true. In Bozkir, honest men are weak. They need to be supported, admired, or encouraged. They should not have to feel obliged to satisfy the needs or expectations of the women they are living with. But the women they know are all dominant and they do not settle for what they are given, they demand more and they do not compromise.

In terms of the police and the juridical system, Bozkır questions the police legitimacy as Masum but it differs from it with emphasis on the power of "evil" on these forces. The protagonist, Seyfi, is a policeman and has a manager named Kaya. Kaya, the chief of police is represented as selfish, coward, and even a little bit fool. The Father of the murdered boy who became devastated and lost his hope in finding the real murderer, says that "A policeman is a slave to his salary and his rank. They protect themselves, not the law", he describes Kaya and others like him with his words. Kaya used to have stomach pain and most of the time, he cannot even concentrate on Seyfi's words due to his pain and advises him to close the case as soon as possible. He is a person easy to deceive. Abbas, the evil, gives financial support to the necessities of the police center and the town, and he manages to make Kaya admire his beneficent personality. 
Figure 2. The Evil and The Chief of Police in Bozkır, Source: Blutv.com Bozkir
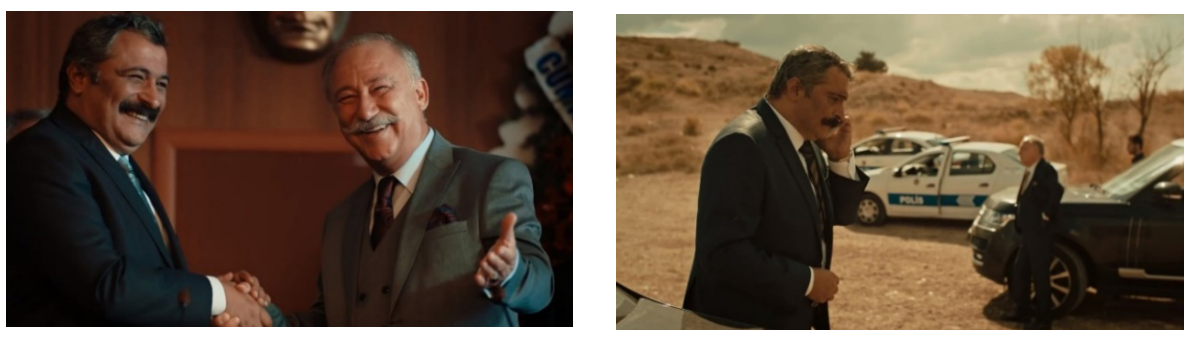

Kaya used to mention Abbas's wealth and influence on the bureaucrats in Ankara says that "I can't afford to make such valuable person nervous for no reason." He wants no trouble in the town to make him have a headache. He even does not hesitate to confess the reason he prefers to be transferred to that small town with his words: "They told me there would be a nice breeze there, but I am burning here." He is far from being an ambitious policeman, and he only cares about his comfort and waits for his retirement.

The omnipotence of evil is also overemphasized in Bozkır, as the dysfunctional presence of the chief police is. Seyfi defines Abbas as "the whale in the steppe". Abbas manages to hide all his murders for long years indeed, however, he has a partner who is as cruel as him and has sadistic desires. His partner helps him to save himself. He, the obsessed ex-lover, functions as the protector of Abbas. What protects Abbas for years is this man's loyalty, not his power. In the end, he quits protecting him and starts to act in a way to make the police realize the murders they committed together. When he is about to be shot by Abbas, he tries to provoke him by saying that he would not let the police arrest him, he says "I won't leave myself to the justice of the ones who are coward and ignorant."

For Abrams (2006, 69), noir is much more than a whodunit. It focuses on the "darkness of human nature" and in the world of noir "there is no safe place to hide and no possibility of escape." Being a country noir makes Bozkır have the town as a non-human character. The town which is used to be named "steppe" in the dialogues of Seyfi and his assistant, functions as an old person who inhibits the change -in a negative way- in the area. It is shown as the reason for the people's ignorance. Abbas' daughter accuses the local people living the steppe of being reckless, she says that they could sleep no matter what happens. People's selfishness makes evil more powerful. In the final scene, every man in the town watches the football game, even the poli- 
cemen on duty, and doctors in the hospital. In addition, Seyfi used to lose his ambition for his job when he talks to Kaya. He tells his assistant that if they closed the case, everybody would be happy. He talks about the insensibility of people, notes that people prefer peace, a life without problem bothering themselves instead of providing justice. Finally, in the "night of horror in the steppe" Seyfi's assistant, more innocent and braver one, the one who has not exposed to the manipulation of justice yet is about to die, while Seyfi, the one who is more experienced, who knows to the hypocrisy of people, who makes fatal mistakes, and is not purely innocent anymore has a chance to survive.

\section{A Hero or a Serial Killer: Șahsiyet (Persona)}

Puhu TV released its second original content Şahsiyet on 17 March 2018, one year later than the release of its first original $F i$. The series was released weekly and spanned 12 episodes whose durations were between 52 to 96 minutes. Şahsiyet is a crime drama based on a revenge-motivated serial killer. Having a serial killer protagonist hunting the criminals who committed a crime collectively in the past, makes the series differ from a usual whodunit. "When the protagonist is a criminal, the story is told from his/her point of view. The narrative is manipulated so audiences will identify with him" (Cobb 1992, 211). The protagonist reveals the reason for his transformation from an ordinary old man into a serial killer in the beginning, and makes the viewer quit focusing on the identities. On the other hand, he does not get any pleasure from murdering as most of the stereotypical serial killers do, he even spends years to find the courage to start murdering. The detective of the series explains the protagonist's situation by saying that "he has so many people to take revenge on that it turns him into a serial killer." Şahsiyet is also an example of film noir. As Conard $(2006,2)$ points out, ambiguity in morality is one the most characteristic themes of film noir, and it is often created via protagonists whose actions are open to be questioned morally, on the contrary of traditional way of character formation which adopts always the good protagonist. Narratives of film noir used to be built on "ambiguous sexual identities, instabilities, and the crossing of traditional boundaries. It feeds on political corruption and moral decadence" (Park 2011, 28).

Agah, the protagonist of Şahsiyet, suffers from remorse for years after witnessing the case about a raped girl and he decides to kill all the criminals who were not punished. A man, who intends to provide justice on his own, dares to become a criminal as a result of his hatred towards the dysfunctional legal system. Şahsiyet underlines the male dominance over females and 
vulnerability of all women in society as a result of the inefficiency of the law. Nevra, the detective of the series is a woman who is also a victim of rape. Despite being a police commissioner, she still faces discrimination from her male colleagues. She is being humiliated or harassed by swearwords.

Before starting the murders, Agah kidnaps a man who killed his wife and was released after being confined only for eight years. Agah uses this man's fingerprints to mislead the crime scene investigation officials. He has a collection of photos of murdered women he took from the criminal records. $\mathrm{He}$ forces this man to watch these photographs to make him feel sorry. He thinks that he wasn't properly punished and says to him: "What is eight years? Unjust provocation, time off for good behavior... Mitigation after mitigation. They could have given a medal too. I have read your trail records. They gave proper consideration but they didn't deal proper retribution." Agah utters his distrust of the juridical system from the beginning of the series.

The case, which Agah had learned about years ago, is about an orphaned twelve-year-old girl who was raped regularly for two years by fifty-two men, and committed suicide after getting pregnant. Agah learns the identities of these fifty-two men from the diary of the girl and starts to hunt them one by one.

The series does not adopt a masculine discourse as usual as most crime dramas do. Agah does not use swearwords as a part of his daily language, he only uses slang words when he gets crazy. Nevra does not use swearwords. However, Nevra works in the police center where masculinity is highly performed. She prefers a masculine style in her outfits and performs masculinity with her body language unconsciously.

Nevra defines the town named Kambura where the little girl was raped by tens of men, as a place where the red riding hoods and wolves are living. She visits the town for the investigation of the case and learns that her primary school teacher had married fifteen years old girl when he was fifty years old.

The town of Şahsiyet resembles the town of Bozkır in some aspects like covering the crimes. It is also revealed that a group of local men got organized to lynch a gypsy family living in Kambura, and they burnt down their house and killed two adults and five children years ago. However, these men do not have any regret for their crime, even they defend themselves. On the other hand, a police commissioner working in Kambura Police Station is a man who 
hinders his duty. He does not care about the cases and slides over them. He does not even charge any policemen to archive the cases digitally for years. The policemen who come from Istanbul ask him that what he did there for three years and he says "Waiting to get assigned to another town." Briefly, the series discriminates the residents of the town by associating them with insensitivity and laziness.

When Nevra visits a psychiatrist about the lynch a gypsy family, the man confesses that he was forced by some people to arrange a fake report about the criminal's mental health when he was working in the Kambura State Hospital. He explains why he preferred to keep silent about the case as:

Normally a fraud uses people's hope. He comes to you and tells you "give me one dollar and I will give you ten back." And if you're greedy by nature, you get hopeful and give him the dollar. Buts the frauds of this country stopped selling hope. There's an easier way. People are so afraid of you. Tell someone you're a cop on the phone and they'll give you every dime. If the frauds of a country con you through fear instead of hope, you never ask them who they are or what they do for a living.

He identifies the man who forced him to arrange the report and it is revealed that the man was the judge of heavy penalty court in Kambura, who had a reputation for taking bribes and was also one of the men who raped the girl in the case.

According to Schuler and Murray (2007, 170), the organization of crime in neo-noir has not a definite form and it resembles the "hydra", which makes the corporation continue to live due to having the ability to reproduce on its own which make it immortal, despite losing some of its men who were killed by the justice. Şahsiyet lets its protagonist get his revenge and achieve his plan. However, the pimp man living in Kambura who also sold the little girl to fifty-two men years ago, still continues to sell kidnaped the little girls locked in his barn.

\section{City and the Reign of Paranoia: Dip (Base)}

Puhu TV released its third original series and second crime drama Dip on 30 March 2018. It spanned eight episodes by weekly releases, each having duration from 57 to 79 minutes. Dip is a crime drama whose subgenre is a mystery. With its melancholic and mentally unhealthy protagonist/detective who is surrounded by people hiding their real identities, and lives in a city where it 
becomes the center of crime at night, makes Dip have noir elements both in its theme and style. As Dixon $(2009,3)$ points out, the real scope of the noir is night and its essential field is the city. Different from the criminals he has to deal with, the protagonist of Dip is even mistaken by his father-like friend about his real identity, and as the secrets of people around him begin to be revealed, this deceived man finds himself in the middle of a paranoid world. For Sanders $(2008,18)$, paranoia in noir is the "way of thinking" rather than being a mood. Dip, as a noir, builds its narrative on the unreliable nature of human which becomes the reason for never-ending paranoia for everyone. The theme of the series is the struggle among two groups who have conflict about the defense system of the country. The fight between good and evil which is based on national benefits is carried on via individual sacrifices of group members.

In terms of gender, Dip has a modernist viewpoint by depicting its female characters, who are middle-class women as powerful and independent. Sahir, the protagonist, sees a man who humiliates a woman in a bar and then he says to his friend: "Men can't handle women. Women are different now." Soon after he meets the same man in the toilet of the bar and beats him to give him a lesson about being kind to women. However, he uses violence too, which underlines the difference between Abraham and Hagar.

Distrust in the police or juridical system is not deeply emphasized in Dip due to being about the conflict between the former members of the intelligence service of the state which makes the police or juridical system less apparent. However, it is not totally left. The members of the group which is represented as the "evil" have more power over the police and juridical system than the good ones. The prosecutor who works on the case defines the reason for death as suicide though it was a murder, as he was told by some people on the "top". The ones who were represented as the evil control the ones who are the head of the juridical system and make them act according to their orders. In addition, Sahir visits a prison where he sees "the independent archive of the country" is being kept there. The man in the basement of the prison who is the head of the secret archive tells Sahir: "Think about it, this must be the only safe place left. Outside these walls is a prison of its own." The "good" ones are hiding in the independent part of a prison from the "bad" ones who totally occupied the outside. The head of the evil team, explains the reason for the change in his decision as: "There is no ideology left. Wealth is the only issue now", which also clarifies the reason for the occupation outside. 
On the other hand, one of the "good" ones says that "for the benefit of the overall good, we may sometimes do some little bad things" and underlines the probability of being a victim for every individual, the impossibility of being an absolute good. Being independent of the issue that was used as the reason for the division between two sides, the good and the evil, Dip protects its noirish pessimism by assigning the power to the evil.

\section{Conclusion: Noir Than Ever}

Re-discovery of crime drama genre with the rise of streaming services around the world can be explained by the gratification they provide to the audience. Having a chance to analyze the crime, the criminals, and question morality as well as choose a side allows viewers to feel "active" in front of their screen. (Robinson 2020, 9). On the other hand, crime dramas have a significant function by impacting the consensus in society and the formation of culture by representing particular ideologies (Clarke 1992, 252). “They shape viewers' fundamental understanding of right and wrong, the role of race and gender in society, how the justice system works and what we should and shouldn't expect from both the system and the people in it" (Mastro 2020, 18).

The representation of police and the juridical system has a critical viewpoint in all of the series studied as cases. These four series: Masum, Bozkır, Şahsiyet and Dip, all question the legitimacy of these institutions and depict a pessimistic landscape with their omnipotent evils who can manipulate all members of the police and juridical system. In all these crime dramas, noir elements they involved both in their themes and styles can be seen. According to Fluck $(2009,288)$, "as a form of social or political criticism, film noir hardly ever goes beyond the sweeping premise of a completely corrupt society and a melodramatic romance of painfully punished nonconformism presented through highly contrived narrative constellations." Indeed, narrations of streamed Turkish noirs cannot go beyond criticism of corrupt society and dysfunctional legal system by not offering any way of solutions or mentioning a probability of an escape for their victims.

Dixon $(2009,4)$ highlights the resemblance between the circumstances of the recent era and the circumstances of the world depicted in noir. He defines the tools of the internet like games, films, chat rooms or websites used by people as an escape tool from the real world, and he says, "we are all 'connected,' yet we have never been more isolated from one another. This is the true message of noir; that today is horrible, and tomorrow will be worse; that hope is an illusion." 
On the other hand, the legitimacy of the police and legal system is not only questioned in crime dramas. Winckles $(2019,251)$ contributes the argument with the example of a very popular original Netflix series: Orange Is the New Black which is a comedy-drama based on a group of women in prison. He defines the series as "ideologically reformist" by revealing the "absurdity" of the carceral system in the United States and forcing the viewer to take a side about mass incarceration. However, he criticizes the series for underlining the impossibility of any actual action or social reform and says, "this could be part of the larger neoliberal goal, to begin with - to make people feel they are aware of an injustice without actually doing much to stop it." This criticism can be read as it is better not to represent an incorrect reality and let people ignore it if they have no chance to recover it. However, it would be unfair to interpret Winckles's argument in this way. It is pretty clear that he criticizes the neutralizing of the prospect for any improvement for the legal system in America by representing the impossibility of receiving a result despite all actions.

Here, Fluck's question about the noir series "How many confirmations of what critics regard as the corrupt state of American society do we actually need?" $(2009,288)$ can be adapted to Turkey. The four series produced by four different private establishments share the same way of representation of the police and juridical system in Turkey. Even though all of them have a consistent criticism about injustice in themselves, when they express it with similar narrations in a chorus-like way, they serve to the normalization of dysfunctional legal system in the end.

The characters of noir used to live under the conditions in which they have no agency on their emergence. These conditions function as a prison for the characters making them feel isolated and, in the end, they get no chance to leave that prison-like world (Sanders 2006, 93). The violent circumstances of today's world can be an explanation of the audience's interest in noirish crime dramas. They may need to get used to the nightmarish world outside and they need to witness it via audiovisual content too, for normalizing the nightmare they are exposed to in real. However, being exposed to the nightmare both in the real and fictional world may result in the internalization of hopelessness in the long run. Woolfolk (2006, 108-109) explains the neutralizing function of noir as below:

The noir worldview denies to the protagonist the realization of either a transformative moment of resistance to its darkness or a triumph of the will to power. Film noir's dark vision does not permit the possibility of an unequivocal charac- 
ter-defining moment of denial because it is set in a world so disenchanted that no ethic of resistance can hold. No compelling symbol system of militant ideals defines the cultural horizon.

As Woolfolk emphasizes, the series studied as cases cannot offer any solution to the problem they depict or mention any possibility of resistance. Rüya, the victim of Masum suffers from a regular abuse of a psychopath man who is actually the chief of police and blackmails her about killing her husband if she gives up meeting him. The final scene of Masum, which left Rüya in her existing desperate situation based on assaults and beatings or perhaps a murder at the end, contributes to the "pessimism" of the series, even in the last second. The evil of the Şahsiyet, is killed in the end, but it is added that the crime, the child abuse continues with other criminals and victims, which evokes the feeling of "loop".

Turkish streaming services take the advantage the new medium which offers them a release from all limiting conditions of the old one. Unsurprisingly, in all four series sexuality, alcohol, and cigarette had been used according to their narratives in forms that cannot be blamed for being unnecessary. It is clear that the characters in these series have freedom about their body, which means they can use it in any way they want, they can have sex with anybody, or they can harm themselves by drinking alcohol or cigarettes. However, defining the narratives of these series as progressive is not possible due to the pessimism in the social context caused by the representation of evil. Freedom of individuals is limited with "body" which is not enough to reach a collective "comfort" or "peace".

All four of the series studied as cases represent the evil as omnipotent and all members of the society as more or less victims. They live in a world where they are trapped as a citizen, whose rights are limited and they are much more vulnerable than they know. Depicting the status quo as unchangeable make these narratives open to be interpreted as conservative. On the other hand, a possible intention of questioning the police legitimacy becomes fruitless when it is repeated again and again in a short time within similar genres and similar ways. As a result, these series can be criticized for normalizing dysfunctional legal system. Also, the emphasis on "no escape" has an impact on neutralizing the prospect for improvement. In summary, it can be claimed that defining the narratives of these series as progressive is not possible, because they cannot manage to position themselves against traditional television series at least for the moment. 


\section{References}

Abrams, Jerold J. 2006. "From Sherlock Holmes to the Hard-Boiled Detective in Film Noir", in The Philosophy of Film Noir, edited by Mark T. Conard, 69-90. Kentucky: The University Press of Kentucky.

Arslan, Savaş. 2005. Melodram. İstanbul: L\&M Yayınları.

Andrews, Elenor. 2014. Place, Setting, Perspective: Narrative Space in The Films of Nanni Moretti. Vancouver: Fairleigh Dickinson University Press.

Borde, Raymond and Etienne Chaumeton. 1995. "Towards a Definition of Film Noir" Accessed December 20, 2020. http://intelligentagent.com/noir/Borde_Chaumeton.pdf

Clarke, Alan. 1992. "'You're Nicked!' Television Police Series and the Fictional Representation of Law and Order" In Come on Down? Popular media culture in post-war Britain, edited by Dominic Strinati and Stephen Wagg, 232-253. London: Routledge.

Cobb, Sharon Y. 1992. "Writing the New Noir Film" Accessed January 8, 2021. http:/ / intelligentagent.com/noir/Cobb.pdf

Conard, Mark T. 2006. “Introduction." In The Philosophy of Film Noir, edited by Mark T. Conard, 1-6. Kentucky: The University Press of Kentucky.

Cooke, Lez. 2008. “The Crime Series” In The Television Genre Book, edited by Glen Creeber. London: Palgrave Macmillan.

Dixon, Wheeler Winston. 2009. Film Noir and the Cinema of Paranoia. Edinburgh: Edinburgh University Press.

Dyer, Richard. 1977. "Homosexuality and Film Noir" Accessed January 18, 2021. http:// www.ejumpcut.org/archive/onlinessays/JC16folder/ HomosexFilmNoir.html

Fluck, Winfried. 2009. "Mass Culture Modernism: Guilt and Subjectivity in Film Noir" In Romance with America? Essays on Culture, Literature, and American Studies, edited by Laura Bieger and Johannes Voelz, 285-319. Heidelberg: Universitatsverlag Winter.

“İnternet televizyonlarına RTÜK denetimi geldi" Accessed November 18, 2020. https: / / www.dw.com/tr/internet-televizyonlar\%C4\%B1na-rt\%C3\%BCkdenetimi-geldi/a-49841223

Kasapoğlu, Çağıl, and Osman Kaytazoğlu. 2018. “Türkiye çocuklarını koruyamıyor mu?" BBC Türkçe, November 20, 2018 Accessed May 5, 2020. https://www.bbc.com/turkce/haberler-turkiye-44824367 
Mastro, Dana. 2020. “Introduction in Normalizing Injustice: The Dangerous Misrepresentations That Define Television's Scripted Crime Genre" Accessed January 20, 2021.

https: / / hollywood.colorofchange.org/crime-tv-report/

Neale, Stephen. 2000a. Genre and Hollywood, London: Routledge.

Neale, Stephen. 2000b. "Questions of Genre" in Film and Theory an Anthology edited by Robert Stam and Toby Miller, New Jersey: Wiley.

Rogers, Margaret. 2008. "Arresting drama: The television police genre, Studies." Learning, Evaluation Innovation and Development, 5(2): 78-84.

Park, William. 2011. What Is Film Noir? Pennsylvania: Bucknell University Press.

Pearson, Roberta. 2007. "Lost in Transition: From Post-Network to Post-Television" In Quality TV: Contemporary American Television and Beyond, edited by Janet McCabe and Kim Akass, 239-256. London; New York: I.B. Tauris.

Robinson, Rashad. 2020. "Foreword" in Normalizing Injustice: The Dangerous Misrepresentations That Define Television's Scripted Crime Genre" 6-15 Accessed January 17, 2021. https: / / hollywood.colorofchange.org/crime-tv-report/

Sanders, Steven M. 2008. “An Introduction to the Philosophy of TV Noir / Noir et Blanc in Color." In The Philosophy of TV noir, edited by Steven M. Sanders and Aeon J. Skoble, 1-32 / 95-114. Kentucky: The University Press of Kentucky.

Sanders, Steven M. 2006. "Film Noir and the Meaning of Life." In The Philosophy of Film Noir, edited by. Mark T. Conard, 91-106. Kentucky: The University Press of Kentucky.

Schuler, Jeanne, and Patrick Murray. 2007. "Anything Is Possible Here" Capitalism, Neo-Noir, and Chinatown." In The Philosophy of Neo-Noir, edited by Mark T. Conard, 167-182. Kentucky: The University Press of Kentucky.

Şentürk, Rıdvan. 2018. “Türk Televizyon Dizileri Efsanesi ve Gerçekler” In Televizyon Dizilerinin Keşfi, edited by Yenal Göksun, 11-38. İstanbul: Kaktüs Yayınları.

Tasker, Yvonne. 2013. “Women in Film Noir.” In A Companion to Film Noir, edited by Andrew Spicer and Helen Hanson, 353-368. New Jersey: Blackwell Publishing.

Tüzün-Ateşalp, Selin. 2016. “Nitelikli Televizyon': Medya Profesyonellerinin Perspektifinden Türk Televizyon Dizilerinde Nitelik." İletişim 25: 9-37. https: / / doi.org/10.16878/gsuilet.283029

Winckles, Andrew O. 2019. Eighteenth-Century Women's Writing and the Methodist Media Revolution. Liverpool: Liverpool University Press 
$148<$ ilef dergisi

Woodhouse, Ben. 2001. "Cop Shows (Police Drama)." In Critical Dictionary of Film and Television Theory, edited by Roberta E. Pearson and Philip Simpson. Newyork: Routledge.

Woolfolk, Alan. 2006. "The Horizon of Disenchantment: Film Noir, Camus, and the Vicissitudes of Descent". In The Philosophy of Film Noir, edited by Mark T. Conard, 107-124. Kentucky: The University Press of Kentucky. 